Regards sur l'économie allemande

Bulletin économique du CIRAC

$116-117 \mid 2015$

Varia

\title{
Culture européenne
}

BÖTTCHER Winfried (ed.), Klassiker des europäischen Denkens. Friedensund Europavorstellungen aus 700 Jahren Kulturgeschichte

\section{(2) OpenEdition}

\section{Journals}

Édition électronique

URL : http://journals.openedition.org/rea/4838

DOI : $10.4000 /$ rea.4838

ISSN : 1965-0787

Éditeur

CIRAC

Édition imprimée

Date de publication : 1 juillet 2015

Pagination : 75

ISSN : 1156-8992

Référence électronique

"Culture européenne », Regards sur l'économie allemande [En ligne], 116-117 | juillet 2015, mis en ligne le 01 juillet 2015, consulté le 22 septembre 2020. URL : http://journals.openedition.org/rea/4838 ; DOI : https://doi.org/10.4000/rea.4838

Ce document a été généré automatiquement le 22 septembre 2020

(C) CIRAC 


\section{Culture européenne}

BÖTTCHER Winfried (ed.), Klassiker des europäischen Denkens. Friedensund Europavorstellungen aus 700 Jahren Kulturgeschichte

\section{RÉFÉRENCE}

BÖTTCHER Winfried (ed.), Klassiker des europäischen Denkens. Friedens- und Europavorstellungen aus 700 Jahren Kulturgeschichte, Nomos Verlagsgesellschaft, Baden-Baden, 2014, $782 \mathrm{p}$.

1 Le politologue BÖTTCHER nous offre là un dictionnaire passionnant de 700 ans de pensée européenne, rassemblant les penseurs innovants - les «classiques 》- entrés dans l'Histoire et rappelant les fondements de notre patrimoine, de la Grèce antique à Charlemagne. L'idée européenne ? Une histoire de guerre et de paix, qui nous transmet ce message: «L'Europe existera quand elle sera entrée dans notre cœur». Isabelle Bourgeois 